\title{
Aquaculture
}

Aquaculture $202(2001) 1-21$

www.elsevier.com/locate/aqua-online

Review article

\section{Penaeid shrimp broodstock nutrition: an updated review on research and development}

\author{
Roeland Wouters ${ }^{\mathrm{a}, *}$, Patrick Lavens ${ }^{\mathrm{b}}$, Julia Nieto ${ }^{\mathrm{a}}$, \\ Patrick Sorgeloos ${ }^{\mathrm{b}}$ \\ ${ }^{\text {a } C E N A I M-E S P O L ~ F o u n d a t i o n, ~ P . O . ~ B o x ~} 0901$ 4519, Guayaquil, Ecuador \\ ${ }^{\mathrm{b}}$ Laboratory of Aquaculture and Artemia Reference Center, Ghent University, Rozier 44, \\ B-9000 Gent, Belgium
}

Received 25 August 2000; accepted 22 January 2001

\begin{abstract}
This paper reviews the current knowledge on shrimp broodstock nutrition with special reference to developments during the last decade. Biochemical studies and diet studies are discussed with the aim of identifying the nutrients that are important to sustain optimal shrimp maturation, reproduction and offspring quality. Additionally, an overview is given of the efforts to reveal the nature of maturation-stimulating factors in fresh food, and of the use and performance of commercial and experimental artificial diets. (C) 2001 Elsevier Science B.V. All rights reserved.
\end{abstract}

Keywords: Shrimp; Broodstock; Maturation; Nutrition; Diet

\section{Introduction}

The limited and inconsistent availability of wild shrimp postlarvae together with an urgent need of establishing selective breeding programs, increased the interest in captive reproduction of penaeids worldwide. The technology for captive reproduction is available for several species, and reviews were published by Primavera (1985), Bray and Lawrence (1992), Ogle (1992) and Browdy (1992, 1998). The availability of an optimal diet is identified as a crucial factor for the sexual maturation and reproduction of shrimp.

\footnotetext{
* Corresponding author. Present address: Laboratory of Aquaculture and Artemia Reference Center, Ghent University, Rozier 44, B-9000 Gent, Belgium. Tel.: +32-9-264-37-54; fax: +32-9-264-41-93.

E-mail address: r.wouters@inve.be (R. Wouters).
} 
The weight of the ovaries of maturing shrimp can increase four- to ninefold (Jeckel et al., 1989; Mourente and Rodriguez, 1991; Ravid et al., 1999; Wouters et al., 1999b) in approximately 1 week and in that time sufficient nutrients need to be accumulated into the egg yolk to sustain the normal development of the embryos and pre-feeding larvae. It has been reported that an unbalanced or incomplete diet causes poor reproductive performance or may even stop animals from reproducing (Bray and Lawrence, 1992). Food does also represent the highest operation cost in most broodstock management facilities (Kawahigashi, 1998). Despite the importance of broodstock nutrition, publications on this topic are limited. In part this may be explained by the demanding character of reproduction trials, e.g. the need for big replicate tanks under controlled conditions, the high operating expense, the labour and the time required to mature animals and to obtain the number of spawns required for a reliable statistical analysis. Harrison (1990, 1997) reviewed work published from the 1970s till the early 1990s with respect to nutrient metabolism during maturation and nutrient requirements for crustacean reproduction. Since then, nutrition research focused on lipid and vitamin requirements, the identification of maturation-stimulating compounds and the development of artificial diets. The present review discusses recent research and trends that may improve our knowledge on shrimp broodstock nutrition and contribute to the development of artificial broodstock diets.

\section{Nutrient requirements}

\subsection{Lipids}

Shrimp do not have an absolute dietary lipid requirement (D'Abramo, 1989). Rather, the provision of sufficient lipid is based upon the satisfaction of requirements for specific nutrients such as highly unsaturated fatty acids (HUFA), phospholipids and sterols, and for energy. Crustaceans have long been recognized as having limited ability to synthesize HUFA de novo (Chang and O'Connor, 1983; Mourente, 1996), and no ability to synthesize sterols de novo (Kanazawa et al., 1988).

\subsection{Total lipids}

There is only one published work on dietary total lipid requirements of shrimp broodstock by Bray et al. (1990b). These authors conducted a reproduction trial with Litopenaeus stylirostris fed three different total lipid levels: $7.8 \%, 11.1 \%$ and $13.9 \%$. Nauplii production and zoea length were higher in the dietary treatment providing $11.1 \%$ total lipids. It should be noted that a feeding regime of $40 \%$ squid and $60 \%$ dry diet was used, and that the $11.1 \%$ lipid level was obtained with an artificial diet that had $10.1 \%$ total lipids. In other words, at the time of formulating artificial diets, one has to keep in mind with which other diets it will be combined and in what proportions. A recent study demonstrated that total dietary lipid levels above $9 \%$ retarded ovarian maturation of $L$. vannamei spawners (Wouters et al., CENAIM-ESPOL Foundation, unpublished data). Table 1 gives the proximate analyses of several experimental and commercial artificial 


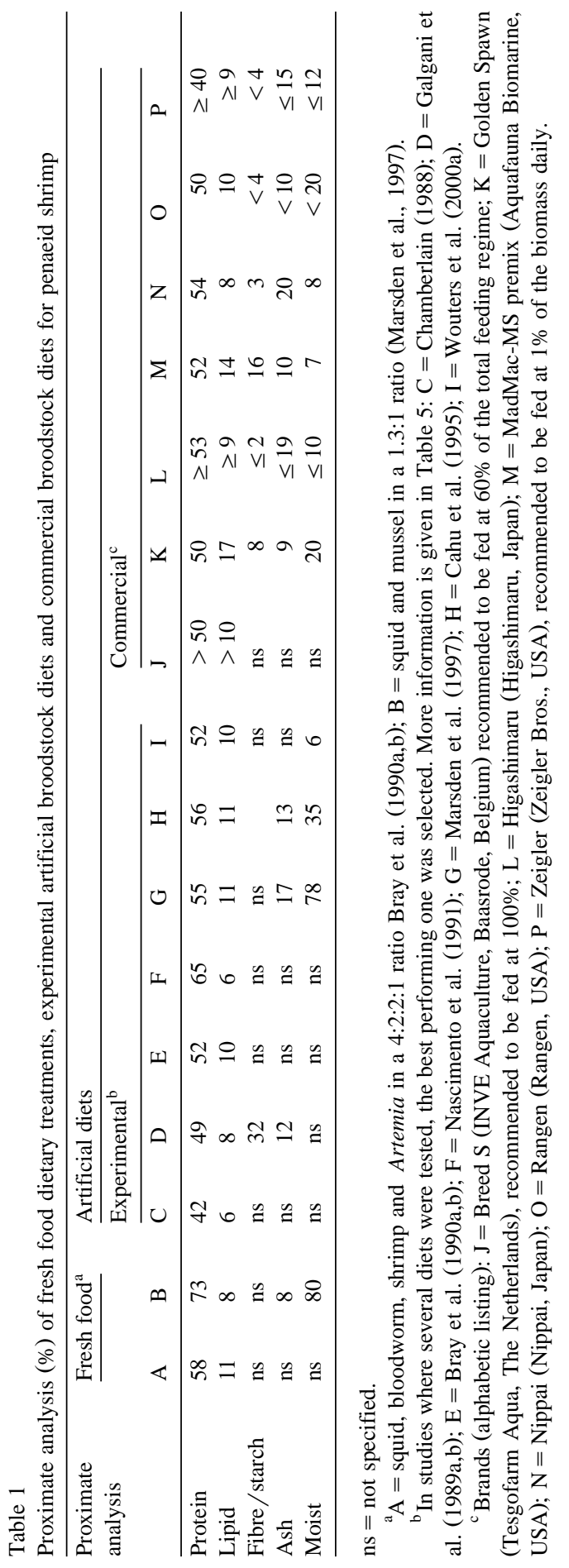


diets. The concentration of total lipid in artificial broodstock diets averages $10 \%$. This is approximately 3\% higher than in grow-out diets for shrimp (Bray et al., 1990a). Some broodstock diets contain lipid levels of $14 \%$ or higher. However, very high dietary lipid levels may affect the ingestion rate in a negative way, given the fact that shrimp get satiated when their energy requirements are met (Aranyakananda and Lawrence, 1994). This may finally result in nutrient deficiencies (D'Abramo, 1997).

There are several publications on the changes in lipid composition of broodstock tissues, eggs and nauplii during ovarian maturation in terms of total lipids, lipid classes and fatty acid profiles. Studying these biochemical parameters allows better understanding of lipid metabolism and dietary lipid requirements in maturing and reproducing shrimp. Such studies have been reported for Farfantepenaeus duorarum (Gehring, 1974), Fenneropenaeus indicus (Galois, 1984), L. setiferus (Middleditch et al., 1980; Castille and Lawrence, 1989), Marsupenaeus japonicus (Teshima and Kanazawa, 1983; Teshima et al., 1989), Melicertus kerathurus (Mourente and Rodriguez, 1991) and Penaeus monodon (Millamena and Pascual, 1990). Earlier work on lipid metabolism provides evidence for the transfer of lipids from the hepatopancreas to the ovary via the haemolymph (Teshima et al., 1988a,b) as demonstrated for M. japonicus during ovarian maturation. In all Penaeid species, an increase of total lipid concentration in the ovaries takes place, and in most species a concomitant decrease of the total lipid level in the hepatopancreas can be observed. It is therefore thought that the hepatopancreas is at the origin of the lipids accumulated in the ovaries. However, an increasing amount of evidence indicates that a major part of the accumulated ovarian lipids originate from the diet. In several studies, the concomitant inverse relationship between ovarian and hepatic lipid levels was not observed (Clarke, 1982; Castille and Lawrence, 1989; Wouters et al., 1999b), and Mourente (1996) demonstrated that the rate of de novo lipid synthesis was too low to contribute significantly to the increase in ovarian lipids.

\subsection{Fatty acids}

In general, the predominant fatty acids in mature ovaries in most Penaeid shrimp species are 16:00, 16:1n-7, 18:00, 18:1n-9, 20:4n-6, 20:5n-3 and 22:6n-3. The ovarian lipids contain higher proportions of $n-3$ HUFA, particularly 20:5n-3 and 22:6n-3, than those of the hepatopancreas, for which it is believed that they play a crucial role in shrimp reproduction. The importance of $n-3$ HUFA has also been deduced from their presence in natural food organisms that are successful maturation diets, e.g. squid and bloodworm (Middleditch et al., 1980; Lytle et al., 1990). Additionally, several studies have evaluated the effect of dietary $n-3$ HUFA levels on broodstock performance. Alava et al. (1993a) obtained retarded ovarian development in M. japonicus fed a HUFA-free diet. Xu et al. (1994) varied the fatty acid composition of a basal broodstock diet by using different lipid sources (anchovy oil, linseed oil, corn oil and pork lard), and fed these diets to $F$. chinensis females. The diet containing anchovy oil resulted in the highest egg $n-3$ HUFA levels, and was the only diet giving a good reproductive output. Positive correlations were found between egg 20:5n-3 levels and fecundity and between egg 22:6n-3 levels and hatching percentage. Therefore, $\mathrm{Xu}$ et 
al. postulate that $20: 5 n-3$ plays a specific role in the ovarian development process, whereas 22:6n-3 may play some other role in early embryogenesis. A similar study was performed by Cahu et al. (1995) with domesticated F. indicus using basal diets containing sunflower oil, cod liver oil, and fish roe oil. The $n-3$ HUFA levels in the eggs were affected by dietary levels, i.e. in the range of $1.44-2.49 \%$ dietary $n-3$ HUFA, the eggs maintained a $n-3$ HUFA level of 3.61-3.82\%, but shrimp fed a diet containing $0.56 \% n-3$ HUFA spawned eggs with lower $n-3$ HUFA $(2.00 \%)$. Hatching percentage was related to dietary $n-3$ HUFA. In an earlier study, Cahu et al. (1994) obtained a drop in the spawning rate of L. vannamei when the broodstock diet was deprived of HUFA and phospholipids. Wouters et al. (1999a) report for $L$. vannamei fed with enriched Artemia biomass, that after replacing the Artemia enrichment product by coconut oil (free of HUFA and cholesterol), a decrease in egg fertilization, repeat performance and egg production per female was observed, yet the maturation frequency was not affected.

Both the fatty acid profiles of wild shrimp tissues (Middleditch et al., 1980) and fresh food (Lytle et al., 1990) have been proposed as comparative tools to evaluate the potential success of broodstock diets. Tables 2 and 3 present some examples taken from publications that reported total lipid fatty acid composition as percentage of total fatty acids. From these tables it can be concluded that considerable differences exist in fatty acid composition between shrimp tissues and fresh food, especially concerning HUFA concentrations. Important differences do also exist among fresh food items. It is as such not easy to decide which fatty acid profile would provide the best comparative tool. Still, the data presented in Table 3 seem to indicate that artificial diets have relatively low concentrations of arachidonic acid (20:4n-6). 20:4n-6 is a HUFA thought to be a precursor in the synthesis of prostaglandins, which may play a role in reproduction (as

Table 2

Fatty acid composition (\% of total fatty acids) of mature ovaries and nauplii of different penaeid species. A selection of pre-dominant fatty acids is presented

\begin{tabular}{|c|c|c|c|c|}
\hline \multirow[t]{2}{*}{ Fatty acid } & \multirow{2}{*}{$\begin{array}{l}\text { L. setiferus } \\
\text { Mature ovaries } \\
(\%)\end{array}$} & \multirow{2}{*}{$\begin{array}{l}\text { M. japonicus } \\
\text { Mature ovaries } \\
(\%)\end{array}$} & \multicolumn{2}{|l|}{ L. vannamei } \\
\hline & & & $\begin{array}{l}\text { Mature ovaries } \\
(\%)\end{array}$ & $\begin{array}{l}\text { Nauplii } \\
(\%)\end{array}$ \\
\hline $16: 00$ & 21.2 & 23.0 & 19.2 & 19.8 \\
\hline $16: 1$ & 10.5 & 20.0 & 11.2 & 9.8 \\
\hline $18: 00$ & 8.8 & 5.3 & 6.7 & 6.9 \\
\hline $18: 1$ & 15.2 & 21.1 & 16.7 & 16.2 \\
\hline $20: 4 n-6$ & 4.1 & 3.6 & 4.8 & 4.3 \\
\hline $20: 5 n-3(\mathrm{EPA})$ & 9.9 & 5.9 & 10.4 & 13.8 \\
\hline $22: 6 n-3$ (DHA) & 7.0 & 7.1 & 7.7 & 8.4 \\
\hline$n-3$ HUFA & $\mathrm{N} / \mathrm{A}$ & $\mathrm{N} / \mathrm{A}$ & 25.5 & 25.0 \\
\hline$n-3 / n-6$ & $\mathrm{~N} / \mathrm{A}$ & $\mathrm{N} / \mathrm{A}$ & 2.0 & 3.1 \\
\hline DHA/EPA & 0.7 & 1.2 & 0.7 & 0.6 \\
\hline Source & $\begin{array}{l}\text { Middleditch et al. } \\
\text { (1980) }\end{array}$ & $\begin{array}{l}\text { Teshima and } \\
\text { Kanazawa (1983) }\end{array}$ & $\begin{array}{l}\text { Wouters et al. } \\
\text { (1999b) }\end{array}$ & \\
\hline
\end{tabular}


Table 3

Fatty acid composition ( $\%$ of total fatty acids) of fresh food items and artificial diets used for shrimp broodstock. A selection of pre-dominant fatty acids is presented

\begin{tabular}{|c|c|c|c|c|c|c|}
\hline \multirow[t]{2}{*}{ Fatty acid } & \multicolumn{3}{|l|}{ Fresh food } & \multicolumn{3}{|c|}{ Artificial diet } \\
\hline & $\begin{array}{l}\text { Bloodworm } \\
(\%)\end{array}$ & $\begin{array}{l}\text { Clam } \\
(\%)\end{array}$ & $\begin{array}{l}\text { Mussel } \\
(\%)\end{array}$ & $\begin{array}{l}\text { Experime } \\
(\%)\end{array}$ & & $\begin{array}{l}\text { Commercial } \\
(\%)\end{array}$ \\
\hline $16: 00$ & 7.5 & 25.0 & 13.6 & 20.7 & 19.4 & 29.2 \\
\hline $16: 1$ & 3.6 & 5.7 & 6.1 & 7.2 & 3.5 & 4.6 \\
\hline 18:00 & 6.5 & 6.8 & 3.0 & 4.3 & 3.3 & 4.9 \\
\hline $18: 1$ & 7.1 & 15.4 & 4.2 & 16.5 & 15.6 & 15.6 \\
\hline $20: 4 n-6$ & 4.1 & 2.4 & 2.7 & 0.8 & 1.1 & 0.3 \\
\hline $\begin{array}{l}20: 5 n-3 \\
\text { (EPA) }\end{array}$ & 29.3 & 18.1 & 15.3 & 8.4 & 10.0 & 4.0 \\
\hline $\begin{array}{l}22: 6 n-3 \\
\text { (DHA) }\end{array}$ & 12.9 & 6.8 & 17.5 & 6.7 & 19.8 & 13.2 \\
\hline$n-3$ HUFA & 52.0 & 24.9 & 33.9 & 15.1 & 31.2 & 17.8 \\
\hline$n-3 / n-6$ & 8.2 & 1.7 & 7.9 & 1.6 & 3.1 & 1.5 \\
\hline DHA/EPA & 0.4 & 0.38 & 1.14 & 0.8 & 2.0 & 3.3 \\
\hline Source & $\begin{array}{l}\text { Lytle et al. } \\
\text { (1990) }\end{array}$ & $\begin{array}{l}\text { Xu et al. } \\
\text { (1994) }\end{array}$ & $\begin{array}{l}\text { Cahu et al. } \\
\text { (1995) }\end{array}$ & $\begin{array}{l}\text { Xu et al. } \\
\text { (1994) }\end{array}$ & $\begin{array}{l}\text { Cahu et al. } \\
\text { (1995) }\end{array}$ & MadMac $^{\text {b }}$ \\
\hline
\end{tabular}

${ }^{\mathrm{a}}$ The best performing artificial diets from these studies are presented.

${ }^{\mathrm{b}}$ Aquafauna Biomarine.

it does in mammals, certain fish and insects; Sargent et al., 1989). Furthermore, artificial diets appear to contain relatively low EPA $(20: 5 n-3)$ concentrations as compared to fresh food (Table 3), resulting in low $n-3$ HUFA concentrations and high DHA/EPA ratios. There is no consensus on the comparative importance of $n-3$ and $n-6$ fatty acids. Actually, very distinct $n-3 / n-6$ ratios are reported for fresh food, shrimp tissues and artificial diets. Lytle et al. (1990) suggest there exists a delicate balance between $n-3$ and $n-6$ fatty acids, and believe that maturation diets should contain high $n-3 / n-6$ ratios. They sustain that, apart from high 20:5n-3 and 22:6n-3 levels, moderate levels of arachidonic acid $(20: 4 n-6)$ should be included into the diet. The $n-3$ and $n-6$ levels reported in the studies of Ravid et al. (1999) and Wouters et al. (1999b) give extra support to this theory. Both studies determined a $n-3$ to $n-6$ ratio of approximately 2 to 1 in the mature ovaries of $P$. semisulcatus and $L$. vannamei spawners, respectively, while in nauplii of $L$. vannamei this ratio increased to 3 to 1 .

\subsection{Lipid classes}

The earlier mentioned biochemical studies on wild shrimp species demonstrated that phospholipids, triacylglycerides (TAG) and cholesterol are the main lipid classes in mature ovaries. During sexual maturation, a remarkable increase of TAG in the ovaries is observed in wild spawners. Ravid et al. (1999) report an increase in ovarian TAG from $1.09 \%$ to $39.65 \%$ in P. semisulcatus. Wouters et al. (1999b) report TAG levels increasing from $8.30 \%$ to $33.81 \%$ in L. vannamei ovaries, followed by a decrease to 
$20.6 \%$ in spent ovaries and a resultant level of $33.5 \%$ in nauplii. TAG appear to be selectively incorporated into the eggs and constitute the principal energy source in eggs and nauplii to support embryogenesis, hatching and naupliar development. The importance of TAG for shrimp reproduction and egg quality is also mentioned in studies by Palacios et al. (1998, 1999a). These authors studied the relationship between reproductive exhaustion and the biochemical composition of eggs, nauplii and postlarvae from domesticated L. vannamei broodstock. They relate the reproductive exhaustion to the diminishing transfer of several biochemical components to the offspring, including TAG and cholesterol. They found positive correlations between these levels and the salinity stress tolerance of the resulting postlarvae.

Phospholipids are predominant in shrimp ovaries, mainly phosphatidylcholine and phosphatidylethanolamine (Gehring, 1974; Teshima and Kanazawa, 1983; Mourente and Rodriguez, 1991; Ravid et al., 1999; Wouters et al., 1999b). Shrimp broodstock seem to have a dietary requirement for phospholipids. Bray et al. (1990b) improved nauplii production, hatching and spermatogenesis in L. stylirostris broodstock by supplementing the diet with $1.5 \%$ soybean lecithin. Alava et al. (1993a) showed that ovarian maturation in $M$. japonicus was retarded when their diet did not contain phospholipids. The dietary phospholipid levels affected phospholipid concentration in L. vannamei eggs in a study performed by Cahu et al. (1994), who sustain that a broodstock diet should contain more than $2 \%$ phospholipids in order to assure that $50 \%$ of the total egg lipids is represented by phospholipids, and for maintaining high spawn frequency and fecundity.

Cholesterol is also an important lipid class in mature shrimp ovaries (Middleditch et al., 1980; Teshima and Kanazawa, 1983; Mourente and Rodriguez, 1991; Ravid et al., 1999; Wouters et al., 1999b). Cholesterol must be provided through the diet for growth of shrimp juveniles (D'Abramo, 1989), and is assumed to be an essential dietary lipid for shrimp maturation and reproduction (Kanazawa et al., 1988). The success of several fresh food items is attributed to their cholesterol content (e.g. squid, clam). Cholesterol is indeed known to fulfill several endocrinological functions, and its mobilization during maturation was reviewed by Harrison (1990). There are no reports on nutrition-reproduction studies with cholesterol.

\subsection{Protein}

It is assumed that protein requirements are higher during maturation and reproduction of animals as compared to the non-reproductive stages, given the intense biosynthesis that takes place during these processes (Harrison, 1990). Artificial diets currently contain around $50 \%$ protein (Table 1). This is $10-20 \%$ higher than a decade ago (Harrison, 1990), but still lower than the protein content of diets that are based on fresh food. However, the optimal dietary protein levels vary with shrimp species and protein source. It is probably more important to address amino acids requirements, as 10 amino acids have been reported to be essential for crustaceans. Deshimaru (1982) recommends dietary amino acid profiles similar to those found in fresh food commonly used in maturation diets. Up to date there are no reports on optimal protein levels, protein:energy ratios or amino acid profiles for shrimp broodstock diets. 
Harrison (1990) mentions the importance of the synthesis of egg yolk proteins, hormone peptides and enzymes during maturation and reproduction, but little information is available on this or on protein levels in shrimp broodstock tissues and eggs. An increase of protein content in the ovaries of F. indicus (Read and Caulton, 1980), Far. aztecus and L. setiferus (Castille and Lawrence, 1989) during maturation has been documented. In L. setiferus, protein levels of testes were higher in mature males than in developing males. Palacios et al. (1999b, 2000) observed a different hepatic and ovarian protein content between females with excellent repeat performance and females with moderate repeat performance of wild and domesticated L. vannamei. The protein contents of the hepatopancreas and the ovaries of the best performing animals were significantly higher. Females that did not spawn had the lowest protein levels in their tissues.

Lubzens et al. (1995) and Ravid et al. (1999) focused on the structure of the haemolymph lipoproteins (e.g. vitellogenin), ovarian lipoproteins (e.g. vitellin) and their role in lipid metabolism. Being insoluble in water, lipids would be transported in the haemolymph as lipoproteins (after binding to vitellogenin).

\subsection{Carbohydrates}

Carbohydrates are not essential for shrimp broodstock. However, they can be a useful inexpensive source of energy with protein-sparing and lipid-sparing effects. Complex sugars and polysaccharides are used more effectively than simple sugars (Deshimaru and Yone, 1978). Starch is most commonly used. Carbohydrates are also excellent binders in diet formulation. Castille and Lawrence (1989) demonstrated an increase in carbohydrate levels of the ovaries of Far. aztecus and L. setiferus. No variation of hepatic levels were observed. Palacios et al. (1998, 1999a) related egg glucose levels with larval quality and broodstock condition.

\subsection{Carotenoids}

Carotenoids are a group of pigments that cannot be biosynthesized by animals. They are taken up from the diet, and can be transformed afterwards from one carotenoid form into another. In juvenile shrimp, they are important for pigmentation. According to recent research, they do also play vital roles in shrimp larvae and broodstock, among which the role of natural anti-oxidant (Dall et al., 1995; Merchie et al., 1998).

During early maturation, free and esterified carotenoids accumulate in the hepatopancreas; during secondary vitellogenesis they are mobilized from there via the haemolymph to the ovaries (Vincent et al., 1988; Harrison, 1990). This accumulation of carotenoids in the ovaries during maturation results in their darkening, on which the "staging" of females into different maturation classes is based. According to Jeckel et al. (1989), the form of the carotenoids that accumulate depends largely on the diet. Dall et al. (1995) conducted biochemical studies on wild P. esculentus, determining astaxanthin and its esters as principal carotenoids. Free astaxanthin was predominant in maturing ovaries (up to $80 \%$ of the total carotenoids), increasing from 2 to $34 \mathrm{ppm}$. In the digestive gland, 
free astaxanthin and esters increased from 20 to $120 \mathrm{ppm}$. In the integument, carotenoid levels remained relatively constant $(90 \mathrm{ppm})$ throughout the maturation cycle. A comparison with carotenoids of the natural diet of $P$. esculentus indicates that after ingestion dietary carotenoids are converted to astaxanthin. Dall et al. do also emphasize that carotenoids play a crucial role as vitamin A precursors.

Wyban et al. (1997) studied the effect of dietary carotenoid on reproductive exhaustion of L. vannamei. At the start of their experiment, broodstock was exhibiting exhaustion symptoms such as color loss in the ovaries and decreased larval survival. Then, paprika (a low-cost carotenoid source) was added to the maturation diet, which resulted in an increased larval survival. This effect on larval quality can probably be attributed to the anti-oxidant properties of carotenoids. Free radicals, initiated by various factors including active oxygen, attack lipids and proteins in biomembranes, leading to a deterioration of egg quality (Bromage and Roberts, 1995). Carotenoids, particularly astaxanthin, are strong scavengers of free radicals and protect eggs from oxidative deterioration. They also prevent peroxidation of poly-unsaturated fatty acids (PUFA) in the diet. Finally, broodstock carotenoids do also play an important role in providing the necessary reserves in embryos and pre-feeding larvae for the development of chromatophores and eyes (Dall et al., 1995).

\subsection{Vitamins}

Fat-soluble vitamins $\mathrm{A}$ (or $\beta$-carotene), $\mathrm{D}$, and $\mathrm{E}$ were found to be essential to support shrimp growth (He et al., 1992). Dietary levels of thiamin, riboflavin, niacin, vitamin $\mathrm{B}_{6}$, vitamin $\mathrm{B}_{12}$, choline, inositol and ascorbic acid have also been recommended for maximal growth in several shrimp species (D'Abramo and Conklin, 1992). Nevertheless, the vitamin requirements for shrimp broodstock are yet to be defined, for which artificial broodstock diets are generally supplemented with a complete vitamin mixture (Table 4).

The vitamins that have been addressed up to date are A, C and E. Vitamin E has been shown to improve the percentage of normal sperm and the rate of ovarian maturation in L. setiferus (Chamberlain, 1988), after diet supplementation with $500 \mathrm{mg} \mathrm{kg}^{-1}$ tocopheryl acetate. In a trial with $F$. indicus spawners Cahu et al. (1991) demonstrated an increase in hatching percentage when increasing dietary $\alpha$-tocopherol levels from 40 to $350 \mathrm{mg} \mathrm{kg}{ }^{-1}$. They noticed a diminishing hatching percentage with spawning rank in the low-vitamin E treatment, which was correlated to a decrease of $\alpha$-tocopherol levels in the egg from $400 \mu \mathrm{g} \mathrm{g}^{-1}$ dry matter (DM) to levels below $200 \mu \mathrm{g} \mathrm{g}^{-1} \mathrm{DM}$. A subsequent study confirmed these findings (Cahu et al., 1995). The $\alpha$-tocopherol egg levels reported by Cahu et al. are very similar to those found in wild L. vannamei by Wouters et al. (1999b), i.e. 325-393 $\mathrm{g} \mathrm{g} \mathrm{g}^{-1} \mathrm{DM} \alpha$-tocopherol in mature ovaries and nauplii. Immature ovaries (stage 0 ) and spent ovaries of $L$. vannamei were found to contain 68 and $124 \mu \mathrm{g} \mathrm{g}^{-1} \mathrm{DM} \alpha$-tocopherol, respectively. Ascorbic acid (vitamin C) levels in $F$. indicus eggs were also affected by the dietary vitamin levels, and high hatch rate of $F$. indicus eggs was related to high ascorbic acid levels in the eggs (Cahu et al., 1995). 


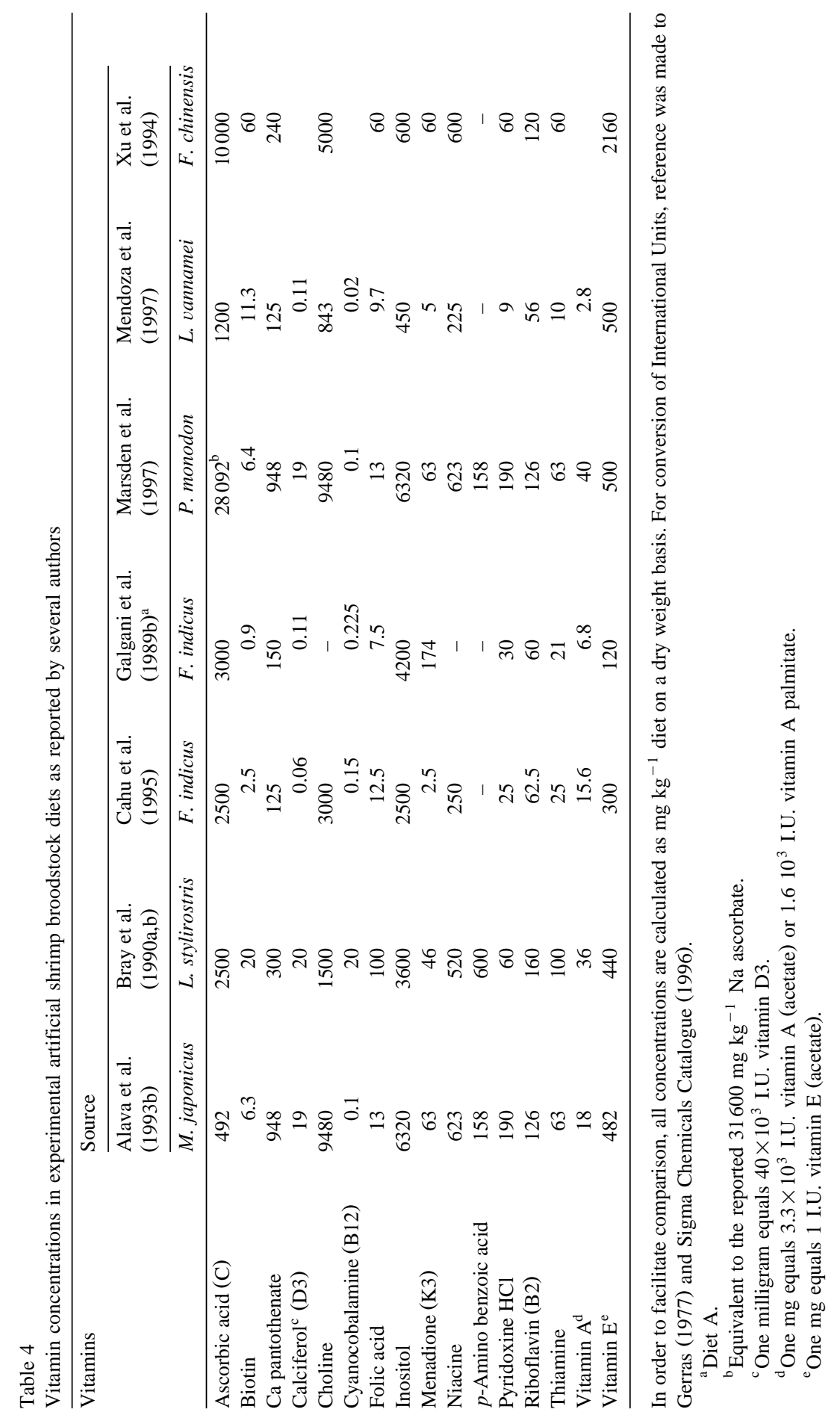


Ovarian maturation is affected by dietary vitamin levels as well. It was demonstrated by Alava et al. (1993b) that ovarian maturation was retarded when diets were deficient in any one of the vitamins E, A and C. Wouters et al. (1999a) demonstrated a positive effect of Artemia biomass enrichment with an $\alpha$-tocopherol acetate/ascorbyl palmitate/astaxanthin mixture on the spawn frequency in L. vannamei broodstock. However, when this vitamin-astaxanthin booster was devoid of high HUFA and cholesterol levels, ovarian maturation and spermatophore regeneration were affected negatively. This negative effect was probably due to over-saturation with the lipo-soluble components vitamin $\mathrm{E}$ and/or astaxanthin. In the presence of HUFA and cholesterol, vitamin $\mathrm{E}$ and astaxanthin appear to be partly used to prevent diet peroxidation.

\subsection{Minerals}

According to Harrison (1990), mineral deficiencies or imbalances could affect crustacean reproduction negatively. Physiological stresses could trigger oocyte resorption or reduce reproductive fitness of the broodstock. Additionally, mineral malnutrition could cause altered composition and quality of the eggs. There are, however, no publications on mineral requirements of shrimp broodstock, probably because of the following complications. Firstly, for minerals it is necessary to distinguish true dietary requirements and apparent physiological requirement, since the minerals can be absorbed from the water. Secondly, the input through animal meals in artificial diets is high, and performing purified diets that would allow controlled mineral levels do not exist. Nevertheless, in most studies with artificial diets mineral mixes were formulated, especially to fortify with calcium, phosphorus, magnesium, sodium, iron, manganese and selenium (Chamberlain, 1988; Alava et al., 1993a,b; Marsden et al., 1997; Mendoza et al., 1997; Xu et al., 1994). The ash levels reported on the technical cards of commercial diets indicate the use of substantial mineral supplements as well (see Table 1).

Méndez et al. (1997) verified the mineral composition of wild L. vannamei broodstock before and after a hatchery cycle. Animals sampled at the end of the hatchery cycle were assumed to be exhausted. Exhausted broodstock exhibited lower levels of calcium and magnesium in the muscle and lower magnesium levels in the hepatopancreas. Moulting and possible transfer to the eggs accompanied by low bio-availability from water and diet could explain this depletion. Copper also decreased in the hepatopancreas, but in the muscle tissue it increased. Possibly, its decrease in the hepatopancreas reflects the transport to the ovaries.

\section{Unknown maturation stimulating compounds in fresh food}

Shrimp maturation and reproduction are greatly influenced by environmental factors (Bray and Lawrence, 1992; Ogle, 1992). In natural conditions, these factors determine the existence of breeding seasons. Breeding seasons are characterized by the presence and availability of specific food organisms, adequate photoperiod and water temperature. 
In the wild, adult shrimp eat a wide variety of microinvertebrates (gastropods, bivalves, crustaceans and polychaetes) and plant material (Rothlisberg, 1998). The changes in the abundance and distribution of these food organisms, or their nutritional quality, explain in part the observed changing pattern of reproductive performance at different times of the year (Crocos and Coman, 1997). In captivity, one tries to mimic breeding season conditions, in an attempt to trigger the hormonal machinery that controls maturation. Fresh or fresh-frozen marine organisms are used for acceptable maturation and reproduction outputs. Often, these marine organisms are found to give the best results when they are in a reproductive stage. Squid and bivalves (mussel, clam, oyster) are generally the main food items, fed at high daily ratios. Crustaceans like shrimp, crab and krill are also fed to shrimp spawners, but due to the risk of disease transmission, they are used less frequently nowadays. Bloodworms (marine polychaetes Glycera dibranchiata and Americonuphis reseii) and Artemia biomass (ongrown Artemia) are used for diet supplementation. Bloodworm is the most expensive ingredient used in hatcheries of the Western atmosphere, and maturation operators feel it to be indispensable for stimulation of ovarian maturation (Kawahigashi, 1998).

Artemia biomass (usually boosted with specific nutrients) has been reported to stimulate ovarian maturation, increase spawn frequency and improve larval quality (Browdy et al., 1989; Naessens et al., 1997; Wouters et al., 1999a). Artemia biomass can also be included into artificial broodstock diets as a freeze-dried meal to increase diet ingestion and stimulate ovarian maturation (Wouters et al., 2000a).

As mentioned earlier, Middleditch et al. (1980) and Lytle et al. (1990) attributed the success of bloodworm to its HUFA composition. On the contrary, Luis and Ponte (1993) provide evidence that the bloodworm effect in Mel. kerathurus is not related to its HUFA level, and also Naessens et al. (1997) replaced bloodworm successfully with Artemia biomass, which has a distinct fatty acid profile. In the study conducted by Cahu et al. (1995), a controlled dietary treatment of fresh mussel gave the highest fecundity and hatch rate results, outcompeting artificial diets that had similar $n-3$ HUFA levels than mussel. While it is clear that HUFA play a crucial role in shrimp reproduction, it should be remembered that lipid quality is not determined by its fatty acid composition only. Care should be taken not to overlook the contribution of nutrients other then HUFA. For example, the high nutritional value of squid is also attributed to its amino acid composition - which is similar to that of shrimp (Shigueno, 1984; Bray et al., 1990a,b) — and because it contains high sterol levels.

The observation that nutrient composition cannot always explain the success of natural food organisms made many researchers believe that reproductive hormones of these organisms contribute to the shrimp endocrinological cycle. This could be true in organisms that share the same hormones as Penaeid shrimp. The role of hormonally active substances has been suggested for Artemia biomass in reproductive stage (Naessens et al., 1997) and bloodworm (Laufer et al., 1998). Laufer found that bloodworms contained methyl farnesoate, which is an ecdysone hormone that increased fecundity and hatch rate in cultured L. vannamei shrimp (Laufer et al., 1997) and $P$. monodon (Hall et al., 1999), and enhanced ovarian development in other crustaceans (Laufer et al., 1998). Conclusive studies regarding the hormonal contribution of diet are non-existent to date, but a study by Mendoza et al. (1997) provides supportive evidence 
to the notion that the so-called "squid factor" might be a hormonally active substance. To identify the effective components in squid that were able to trigger secondary vitellogenesis, squid meal was separated into different extracts by these authors. Each extract was incorporated into an artificial diet and fed to L. vannamei females to verify their effect on ovarian maturation and haemolymph vitellogenin concentrations. The results show that squid, apart from being a rich cholesterol source, contains sexual steroids that trigger shrimp vitellogenesis. Similar findings are reported for the effect of mollusc extracts on M. japonicus vitellogenesis (Kanazawa, 1989, cited in Mendoza et al., 1997).

\section{Artificial diets}

According to a survey conducted among commercial hatcheries in the Western hemisphere (Kawahigashi, 1998), the development of artificial broodstock diets capable of replacing the fresh food is a priority. A lot of advantages can be expected from dry artificial diets over fresh food, e.g. reliable supply, reproducible and controlled quality, easy to use, improved stability under storage, reduced tank fouling, reduced risk of disease introduction and easy delivery of chemotherapeutics, immunostimulants, and/or hormones (Harrison 1990, 1997). Nevertheless, almost every attempt to completely replace fresh food with artificial diets, results in a decrease in ovarian maturation, a reduced number of spawns and an inferior egg quality. In most situations, a combination of fresh food and artificial diets gives better results than a feeding regime that consist of fresh food only (Bray et al., 1990a,b; Galgani et al., 1989a,b; Nascimento et al., 1991).

In commercial maturation facilities, the use of artificial maturation diets is common, but only in low proportions. The results of a recent survey on the use of artificial diets in the Western hemisphere (Wouters et al., 2000b) are presented in Table 5. Most hatcheries work with L. vannamei shrimp. The survey reveals that $80 \%$ of the hatcheries with maturation facilities include artificial broodstock diets in the feeding regime on a routine basis. It was estimated that on average only $16 \%$ of the total feeding regime is constituted by an artificial broodstock diet. Only in a minority $(15 \%)$ of the hatcheries do artificial diets represent more than $25 \%$ of the total feeding regime. The commercial diets that are used are Breed S (INVE Aquaculture), Higashimaru (Higashimaru),

Table 5

Feeding rates (daily \% of shrimp biomass) and ratio of artificial broodstock diets used in commercial hatcheries $(n=19)$ of the Western hemisphere (Wouters et al., 2000b)

\begin{tabular}{|c|c|c|c|c|}
\hline \multirow[t]{2}{*}{ Parameter } & \multicolumn{2}{|c|}{ Wet weight basis } & \multicolumn{2}{|c|}{ Dry weight basis } \\
\hline & Mean & Range & Mean & Range \\
\hline Total feeding rate $(\% /$ day $)$ & 18.8 & $5.0-31.0$ & 5.0 & $2.3-8.2$ \\
\hline Artificial diet feeding rate $(\% /$ day $)$ & 1.0 & $0-4.0$ & 0.9 & $0-3.5$ \\
\hline Ratio artificial /total (\%) & na & na & 16.0 & $0-53.0$ \\
\hline
\end{tabular}

na $=$ not applicable. 
MadMac-MS (Aquafauna Biomarine), Nippai (Japan), Rangen (Rangen) and Zeigler (Zeigler Bros.). One hatchery has its own diet made by a feed manufacturer. The most popular diet is a dry premix, preferred by many panelists because it allows mixing with essential nutrients, minced fresh food and/or chemicals. It was also observed that many of the maturation operators that reported the use of artificial diets did not reduce the fresh food feeding rate. In such a case, artificial diets do only represent a diet supplement. To readily increase the ratio of artificial broodstock diets, the fresh food feeding rate should be reduced taking into account that the dry matter content of dry artificial diets is approximately fivefold that of fresh food ingredients. One respondent from South Africa uses $47 \%$ artificial diets in the feeding regime of wild and domesticated $F$. indicus. One hatchery in Australia fed domesticated $P$. monodon and $F$. merguiensis with $70 \%$ home-made artificial diet. In Asia, captive shrimp reproduction depends much more on wild gravid females than in other regions. Therefore, most Asian maturation systems are designed for spawning gravid females only, and maturation diets are based exclusively upon the use of local fresh food items (Chris Dinneweth, INVE Technologies, personal communication).

The observed low fresh food replacement levels on commercial scale have much to do with the fact that commercial broodstock diets are not performing as well as fresh diets. Hence, diet formulation depends on a limited knowledge of the nutrient requirements of adult shrimp during maturation and reproduction. To reduce the risk that the nutrient requirements of reproducing shrimp might not be met by the diet, the following formulation practices are generally adapted:

1. High levels of essential nutrients are formulated, including vitamins (see Table 4), astaxanthin, $n-3$ HUFA, cholesterol and lecithin.

2. Practical ingredients of premium quality are used: animal meals and oils of marine origin (squid, shrimp, krill, cold-water fish), fish solubles, yeast, and algae.

However, over-fortification or an improper nutrient balance may affect the reproductive performance in a negative way. Finally, the use of premium ingredients for diets that already serve a limited market, makes them rather expensive.

In research trials, the fresh food replacement levels are often higher than those applied in commercial facilities, which has had its consequences for spawner survival, spawn frequency, fecundity, egg fertilization rate, hatch rate and/or larval quality (Table 6). Many authors have successfully used dry artificial broodstock diets at $50 \%$ of the total feeding regime, even when bloodworm and Artemia biomass were replaced partially (Coutteau et al., 1998) or completely (Wouters et al., 2000a) in commercial-scale trials. When artificial diets are fed at a higher rate, results can be either negative, neutral or positive. Fig. 1 summarizes the effect of increasing fresh food replacement levels with an experimental artificial diet on L. vannamei ovarian development and survival (Wouters et al., CENAIM-ESPOL Foundation, unpublished data). Xu et al. (1994) fed $100 \%$ semi-purified diets to $F$. chinensis without affecting reproductive performance as compared to a clam control diet. However, it has been shown that treatments based on a single fresh food are not optimal (Chamberlain, 1988; Bray et al., 1990a,b), for which 


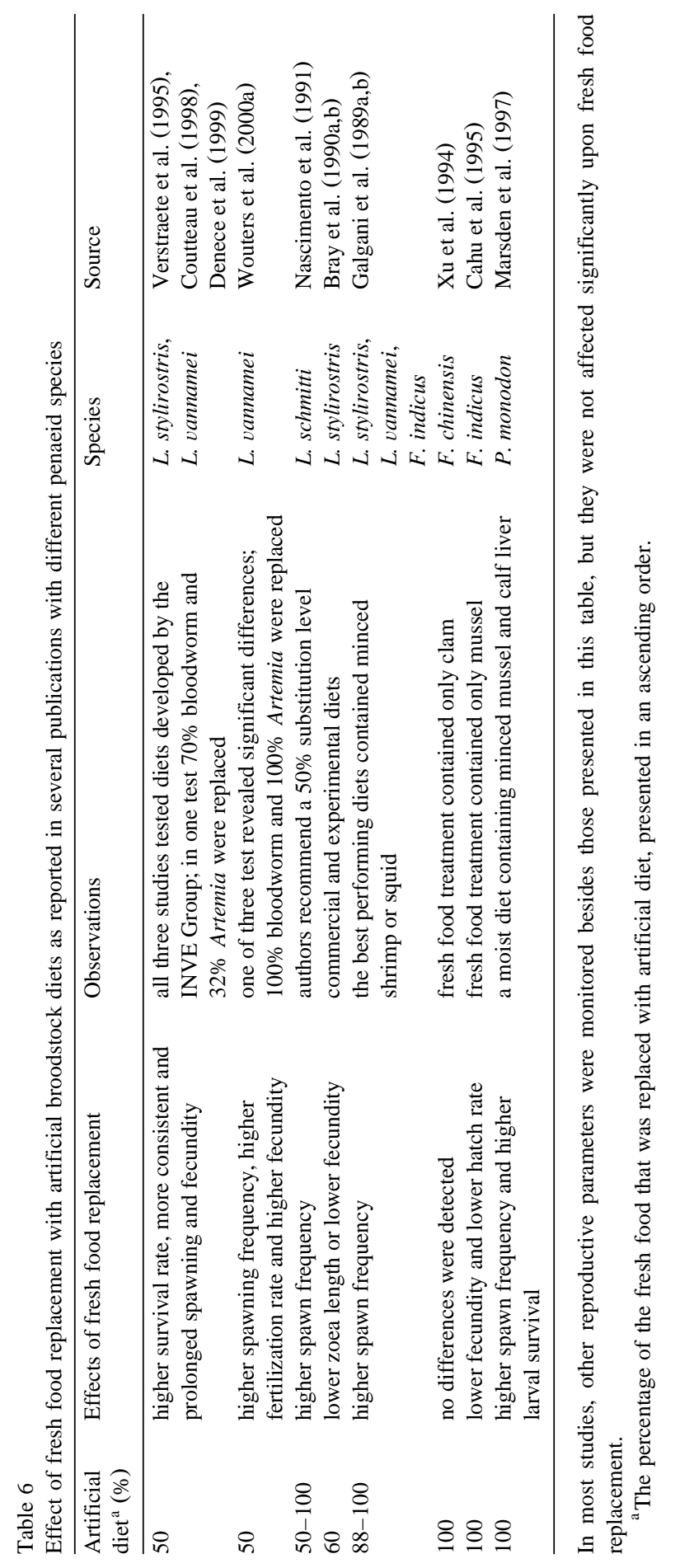




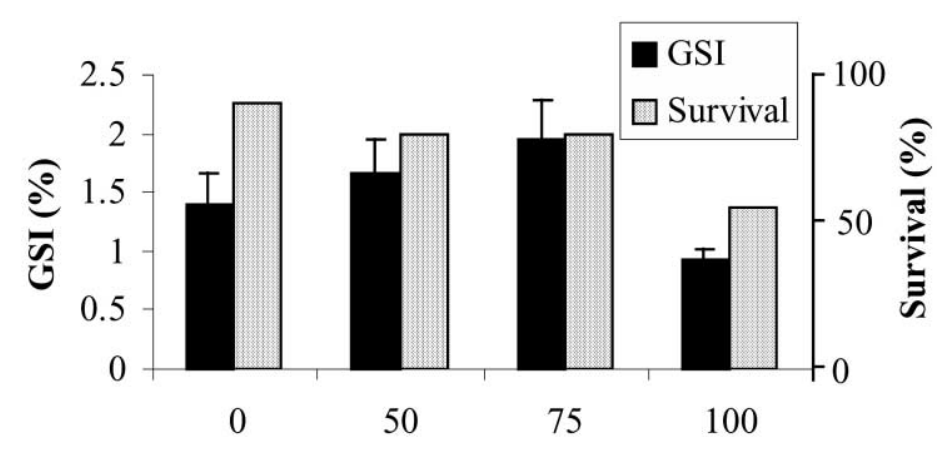

Fresh food replacement level (\%)

Fig. 1. The effect of increasing fresh food replacement levels with an experimental artificial diet on $L$. vannamei ovarian development (Gonadosomatic index, GSI = (ovarian wet weight $/$ whole body wet weight $) \times$ $100 \%$ ) and survival (\%) (Wouters et al., CENAIM-ESPOL Foundation, unpublished data).

the clam diet might not be considered an adequate control for comparison with artificial diets. If so, the only studies that obtained promising results with $100 \%$ fresh food replacement are those reported by Galgani et al. (1989a,b) and Marsden et al. (1997). Interestingly, both authors report the inclusion of minced fresh food into the artificial diet. Marsden et al. (1997) further mention that a soft moist pellet had to be prepared to ensure sufficient diet ingestion. Though their findings contribute significantly to our efforts in developing performing shrimp broodstock diets, moist diets generally have a shorter shelf-life and a lower water stability then dry diets, which is why they are not commercially available.

\section{Conclusion}

Recent broodstock nutrition studies have contributed further to a better knowledge of the requirements of lipids, vitamins and carotenoids for the maturation process in Penaeid shrimp. Biochemical studies have detected high levels of TAG, phospholipids and cholesterol in the ovaries of mature shrimp, eggs and nauplii. Furthermore, $n-3$ HUFA were shown to be the predominant fatty acids in the tissues of shrimp broodstock and its offspring, and their importance was confirmed through diet studies. While the fatty acid profile of natural food organisms is classically used to predict their suitability for shrimp broodstock nutrition, some studies demonstrated that other nutrients and hormonally active dietary substances do also play a crucial role in the stimulation of ovarian maturation. Biochemical and experimental work provided increasing evidence of the important role of natural anti-oxidants for optimal shrimp maturation, reproduction and larval quality, namely carotenoids and vitamins $\mathrm{E}$ and $\mathrm{C}$.

Still, our knowledge on the specific nutrient requirements of shrimp broodstock remains limited. Only purified or semi-purified artificial diets could provide the neces- 
sary tools to investigate the effect of certain nutrients on ovarian maturation, reproduction and offspring quality. This would be particularly useful for studying the requirements for dietary protein, amino acid profiles, energy:protein ratios and minerals, all of these being topics that remained unaddressed up to date. Even in the case of lipids, carotenoids and vitamins, questions remain as far as the quantitative requirements, nutrient interactions and nutrient metabolism are concerned. Biochemical studies can give further insight in metabolic pathways and provide useful tools to estimate nutrient requirements, to asses suitability of fresh food items for broodstock nutrition, and to determine egg quality and larval quality. Male reproducer nutrient requirements for optimal spermatophore development and high sperm quality should receive special attention, as most publications focused on females only.

The development of performing dry diets that allow the complete replacement of fresh food is a research priority as well. Once our knowledge of the nutritional requirements and endocrinology of shrimp broodstock has improved, it will be possible to formulate artificial diets in such a way that a high, consistent and prolonged reproductive performance will be ensured without the need of eye-stalk ablation. The challenge will be to do it in a cost-effective manner at commercial scale.

\section{References}

Alava, V.R., Kanazawa, A., Teshima, S., Koshio, S., 1993a. Effect of dietary phospholipids and $n-3$ highly unsaturated fatty acids on ovarian development of Kuruma prawn. Nippon Suisan Gakkaishi 59 (7), $345-351$.

Alava, V.R., Kanazawa, A., Teshima, S., Koshio, S., 1993b. Effect of dietary vitamins A, E and C on the ovarian development of Penaeus japonicus. Nippon Suisan Gakkaishi 59 (7), 1235-1241.

Aranyakananda, P., Lawrence, A.L., 1994. Effects of ingestion rate on dietary protein and energy requirements of Penaeus vannamei and the optimal protein to energy ratio. Memorias 2 Simposio en Nutrición Acuícola. Monterrey, México, pp. 1-19.

Bray, W.A., Lawrence, A.L., 1992. Reproduction of Penaeus species in captivity. In: Fast, A., Lester, L.J. (Eds.), Marine Shrimp Culture: Principles and Practices. Elsevier, Amsterdam, The Netherlands, pp. 93-170.

Bray, W.A., Lawrence, A.L., Leung-Trujillo, J.R., 1990a. Reproductive performance of ablated Penaeus stylirostris fed a soy lecithin supplement. J. World Aquacult. Soc. 20, 19A.

Bray, W.A., Lawrence, A.L., Lester, L.J., 1990b. Reproduction of eyestalk-ablated Penaeus stylirostris fed various levels of total dietary lipid. J. World Aquacult. Soc. 21, 41-52.

Bromage, N.R., Roberts, J.R., 1995. Broodstock management and egg and larval quality. Blackwell Science, Oxford, UK.

Browdy, C.L., 1992. A review of the reproductive biology of Penaeus species: perspectives on controlled shrimp maturation systems for high quality nauplii production. In: Wyban, J. (Ed.), Proceedings of the special session on shrimp farming, World Aquaculture Society, Orlando, FL, USA. World Aquaculture Society, Baton Rouge, LA, USA, pp. 22-51.

Browdy, C.L., 1998. Recent developments in penaeid broodstock and seed production technologies; improving the outlook for superior captive stocks. Aquaculture 164, 3-21.

Browdy, C.L., Hadani, A., Samocha, T.M., Loya, 1989. An evaluation of frozen Artemia as a dietary supplement for the stimulation of reproduction in Penaeid shrimp. Aquaculture-A Biotechnology in Progress. European Aquaculture Society, Bredene, Belgium, pp. 617-623.

Cahu, C., Fakhfakh, M., Quazuguel, P., 1991. Effect of dietary $\alpha$-tocopherol level on reproduction of Penaeus 
indicus. In: Lavens, P., Sorgeloos, P., Jaspers, E., Ollevier, F. (Eds.), LARVI '91—Fish and Crustacean Larviculture Symposium, Special Publication, vol. 15, European Aquaculture Society, Gent, Belgium, pp. $242-244$.

Cahu, C.L., Guillaume, J.C, Stéphan, G., Chim, L., 1994. Influence of phospholipid and highly unsaturated fatty acids on spawning rate and egg tissue composition in Penaeus vannamei fed semi-purified diets. Aquaculture 126, 159-170.

Cahu, C.L., Cuzan, G., Quazuguel, P., 1995. Effect of highly unsaturated fatty acids, alpha-tocopherol and ascorbic acid in broodstock diet on egg composition and development of Penaeus indicus. Comp. Biochem. Physiol. 112 (3-4), 417-424.

Castille, F.L., Lawrence, A.L., 1989. Relationship between maturation and biochemical composition of the gonads and digestive glands of the shrimps Penaeus aztecus Ives and Penaeus setiferus (L.). J. Crustacean Biol. 9 (2), 202-211.

Chamberlain, G.W., 1988. Stepwise investigation of environmental and nutritional requirements for reproduction of penaeid shrimp. PhD dissertation, Department of Wildlife and Fisheries Science, Texas A\&M University, TX, USA.

Chang, E., O’Connor, J., 1983. Metabolism and transport of carbohydrates and lipids. In: Bliss, D.E. (Ed.), The Biology of Crustacea, 5, Academic Press, New York, pp. 263-287.

Clarke, A., 1982. Lipid synthesis and reproduction in the polar shrimp Chorismus antarticus. Mar. Ecol. Prog. Ser. 9 (1), 81-90.

Coutteau, P., Pinon, E., Balcazar, Y., 1998. Effect of a commercial maturation diet on broodstock performance of Penaeus vannamei in a commercial hatchery. 1st Latin American Shrimp Culture Congress and Exhibition, Panama City, Panama. Abstract.

Crocos, P.J., Coman, G.J., 1997. Seasonal and age variability in the reproductive performance of Penaeus semisulcatus broodstock: optimising broodstock selection. Aquaculture 155 (1-4), 55-67.

D’Abramo, L.R., 1989. Lipid requirements of shrimp. Advances in Tropical Aquaculture. AQUACOPIFREMER, Tahiti, pp. 271-285.

D’Abramo, L.R., 1997. Triacylglycerol and fatty acids. In: Halver, E. (Ed.), Crustacean Nutrition, vol. 6, World Aquaculture Society, Baton Rouge, LA, pp. 71-84.

D’Abramo, L.R., Conklin, D.E., 1992. New developments in the understanding of the nutrition of penaeid and caridean species of shrimp. In: Browdy, C.L., Hopkins, S.J. (Eds.), Swimming Through Troubled Water. Proceedings of the Special Session on Shrimp Farming, Aquaculture '95, World Aquaculture Society, Baton Rouge, LA, USA, pp. 95-107.

Dall, W., Smith, D.M., Moore, L.E., 1995. Carotenoids in the tiger prawn Penaeus esculentus during ovarian maturation. Mar. Biol. 123 (3), 435-441.

Denece, E., Pham, D., Coutteau, P., 1999. Reproductive response of Penaeus stylirostris to a 50\% substitution of fresh food by a new shrimp maturation feed. Book of Abstracts, Aquaculture '99. World Aquaculture Society, Sydney, Australia, p. 601.

Deshimaru, O., 1982. Protein and amino acid nutrition of the prawn, Penaeus japonicus. Proceedings of the 2nd International Conference on Aquaculture Nutrition: Biochemical and Physiological Approaches to Shellfish Nutrition. World Mariculture Society, Special Publication, vol. 2, Louisiana State University, Baton Rouge, Louisiana, USA, pp. 106-122.

Deshimaru, O., Yone, Y., 1978. Effect of dietary carbohydrate sources on the growth and feed efficiency of prawn. Bull. Jpn. Soc. Sci. Fish. 44, 1161-1163.

AQUACOP, Galgani, M.L., 1989a. Influence du régime alimentaire sur la reproduction en captivité de Penaeus vannamei and Penaeus stylirostris. Aquaculture 80, 97-109.

Galgani, M.L., Cuzon, G., Galgani, F., Goguenheim, J., 1989b. Influence du régime alimentaire sur la reproduction en captivité de Penaeus indicus. Aquaculture 81, 337-350.

Galois, R.G., 1984. Variations de la composition lipidique tissulaire au cours de la vitellogenese chez la crevette Penaeus indicus Milne Edwards. J. Exp. Mar. Biol. Ecol. 84, 155-166.

Gehring, W.R., 1974. Maturational changes in the ovarian lipid spectrum of the pink shrimp Penaeus duorarum Burkenroad. Comp. Biochem. Physiol. 49A, 511-524.

Gerras, C., 1977. The Complete Book of Vitamins. Rodale Press, Emmaus, PA.

Hall, M.R., Mastro, R., Prestwich, G., 1999. Horminal modulation of spawner quality in Penaeus monodon. 
Book of Abstracts, World Aquaculture '99. World Aquaculture Society, Sydney, Australia, p. 308, Abstract.

Harrison, K.E., 1990. The role of nutrition in maturation, reproduction and embryonic development of decapod crustaceans: a review. J. Shellfish Res. 9 (9), 1-28.

Harrison, K.E., 1997. Broodstock nutrition and maturation diets. In: D’Abramo, L.R., Conklin, D.E., Akiyama, D.M. (Eds.), Crustacean nutrition. Advances in World Aquaculture, The World Aquaculture Society, vol. 6, pp. 390-408.

He, H., Lawrence, A.L., Liu, R., 1992. Evaluation of dietary essentiality of fat-soluble vitamins, A, D, E and $\mathrm{K}$ for penaeid shrimp (Penaeus vannamei). Aquaculture 103, 177-185.

Jeckel, W.H., Aizpun de Moreno, J.E., Moreno, V.J., 1989. Biochemical composition, lipid classes and fatty acids in the ovary of the shrimp Pleoticus muelleri Bate. Comp. Biochem. Physiol. 92B, 271-276.

Kanazawa, A., 1989. Maturation diets. Oral Presentation, 1st session of "Nutrition in Crustaceans". Advances in Tropical Aquaculture. Tahiti, February 20-March 4. Abstract only.

Kanazawa, A., Chim, L., Laubier, L., 1988. Tissue uptake of radioactive cholesterol in the prawn Penaeus japonicus Bate during ovarian maturation. Aquat. Living Resour. 1, 85-91.

Kawahigashi, D.K., 1998. Overview of commercial maturation technology in the Western hemisphere. Recife Brazil LAC WAS Conference Proceedings, vol. 98, Anais de Aquicultura, Brazil, pp. 381-392.

Laufer, H., Paddon, J., Paddon, M., 1997. A hormone enhancing larva production in the pacific white shrimp, Penaeus vannamei. IV symposium on aquaculture in Central America: focusing on shrimp and tilapia, Tegucigalpa, Honduras, Asociación Nacional de Acuicultores de Honduras and the Latin American Chapter of the World Aquaculture Society, pp. 161-162.

Laufer, H., Biggers, W.J., Ahl, J.S.B., 1998. Stimulation of ovarian maturation in the crayfish Procambarus clarkii by methyl farnesoate. Gen. Comp. Endocrinol. 111, 113-118.

Lubzens, E., Khayat, M., Ravid, T., Funkenstein, B., Tietz, A., 1995. Lipoproteins and lipid accumulation within the ovaries of penaeid shrimp. Isr. J. Aquacult.-Bamidgeh 47 (3-4), 185-195.

Luis, O.J., Ponte, A.C., 1993. Control of reproduction of the shrimp Penaeus kerathurus. J. World Aquacult. Soc. 24, 31-39.

Lytle, J.S., Lytl, T.F., Ogle, J., 1990. Polyunsaturated fatty acid profiles as a comparative tool in assessing maturation diets of Penaeus vannamei. Aquaculture 89, 287-299.

Marsden, G.E., McGuren, J.J., Hansford, S.W., 1997. A moist artificial diet for prawn broodstock: its effect on the variable reproductive performance of wild caught Penaeus monodon. Aquaculture 149, 145-156.

Méndez, L., Acosta, B., Racotta, I.S., 1997. Mineral concentrations of Penaeus vannamei broodstock in a hatchery. IV symposium on aquaculture in Central America: focusing on shrimp and tilapia, Tegucigalpa, Honduras, Asociación Nacional de Acuicultores de Honduras and the Latin American Chapter of the World Aquaculture Society, pp. 163-165.

Mendoza, R., Revol, A., Fauvel, C., Patrois, J., Guillaume, J.-C., 1997. Influence of squid extracts on the triggering of secondary vitellogenesis in Penaeus vannamei. Aquacult. Nutr. 3, 55-63.

Merchie, G., Kontara, E., Lavens, P., Robles, R., Kurmaly, K., Sorgeloos, P., 1998. Effect of vitamin C and astaxanthin on stress and disease resistance of postlarval tiger shrimp, Penaeus monodon (Fabricius). Aquacult. Res. 29, 579-585.

Middleditch, B.S., Missler, S.R., Hines, H.B, McVey, J.B., Brown, A., Ward, D.G., Lawrence, A.L., 1980. Metabolic profiles of penaeid shrimp: dietary lipids and ovarian maturation. J. Chromatogr. 195, 359-368.

Millamena, O.M., Pascual, F.P., 1990. Tissue lipid content and fatty acid composition of Penaeus monodon Fabricius broodstock from the wild. J. World Aquacult. Soc. 21, 116-121.

Mourente, G., 1996. In vitro metabolism of C-14-polyunsaturated fatty acids in midgut gland and ovary cells from Penaeus kerathurus Forskal at the beginning of sexual maturation. Comp. Biochem. Physiol. 115 (2), $255-266$.

Mourente, G., Rodriguez, A., 1991. Variation in the lipid content of wild-caught females of the marine shrimp Penaeus kerathurus during sexual maturation. Mar. Biol. 110, 21-28.

Naessens, E., Lavens, P., Gómez, L., Browdy, C., McGovern-Hopkins, K., Spencer, A., Kawahigashi, D., Sorgeloos, P., 1997. Maturation performance of Penaeus vannamei co-fed Artemia biomass preparations. Aquaculture 155, 87-101

Nascimento, I.A., Bray, W.A., Leung-Trujillo, J.R., Lawrence, A.L., 1991. Reproduction of ablated and 
unablated Penaeus schmitti in captivity using diets consisting of fresh-frozen natural and dried formulated feeds. Aquaculture 99, 387-398.

Ogle, J.T., 1992. A review of the current (1992) state of our knowledge concerning reproduction in open thelicum Penaeid shrimp with emphasis on Penaeus vannamei. Gulf Res. Rep. 22 (1-3), 267-274.

Palacios, E., Ibarra, A.M., Ramirez, J.L., Portillo, G., Racotta, I.S., 1998. Biochemical composition of eggs and nauplii in White Pacific Shrimp, Penaeus vannamei (Boone), in relation to the physiological condition of spawners in a commercial hatchery. Aquacult. Res. 29, 183-189.

Palacios, E., Perez-Rostro, C.I., Ramirez, J.L., Ibarra, A.M., Racotta, I.S., 1999a. Reproductive exhaustion in shrimp (Penaeus vannamei) reflected in larval biochemical composition, survival and growth. Aquaculture $171(3 / 4), 309-321$.

Palacios, E., Racotta, I.S., 1999b. Spawning frequency analysis of wild and pond-reared Pacific White Shrimp, Penaeus vannamei broodstock under large-scale hatchery conditions. J. World Aquacult. Soc. 30 (2), $180-191$.

Palacios, E., Ibarra, A.M., Racotta, I.S., 2000. Tissue biochemical composition in relation to multiple spawning in wild and pond-reared Penaeus vannamei broodstock. Aquaculture 185, 353-371.

Primavera, J., 1985. A review of maturation and reproduction in closed thelycum penaeids. Proceedings of the First International Conference on the Culture of Penaeid Prawns/Shrimps. SEAFDEC Aquaculture Department, Iloilo City, Philippines, pp. 47-64.

Ravid, T., Tietz, A., Khayat, M., Boehm, E., Michelis, R., Lubzens, E., 1999. Lipid accumulation in the ovaries of a marine shrimp Penaeus semisulcatus (De Haan). J. Exp. Biol. 202 (13), 1819-1829.

Read, G.H.L., Caulton, M.S., 1980. Changes in mass and chemical composition during the molt cycle and ovarian development in inmature and mature Penaeus indicus Milne Edwards. Comp. Biochem. Physiol. 66A, 431-437.

Rothlisberg, P.C., 1998. Aspects of penaeid biology and ecology of relevance to aquaculture; a review. Aquaculture 164, 49-65.

Sargent, J., Henderson, R.J., Tocher, D.R., 1989. The lipids. In: Halver, J.E. (Ed.), Fish Nutrition. Academic Press, London, UK, pp. 153-219.

Shigueno, K., 1984. Intensive culture and feed development in Penaeus japonicus. Proceedings of the First International Conference on the Culture of Penaeid Prawns/Shrimps, Iloilo City, Philippines.

Teshima, S., Kanazawa, A., 1983. Variation in lipid composition during the ovarian maturation of the prawn. Bull. Jpn. Soc. Sci. Fish. 49 (6), 957-962.

Teshima, S., Kanazawa, A., Koshio, S., Horinouchi, K., 1988a. Lipid metabolism in destalked prawn Penaeus japonicus: induced maturation and accumulation of lipids in the ovaries. Nippon Suisan Gakkaishi 54 (7), 1115-1122.

Teshima, S., Kanazawa, A., Horinouchi, K., Koshio, S., 1988b. Lipid metabolism in destalked prawn Penaeus japonicus: induced maturation and transfer of lipid reserves to the ovaries. Nippon Suisan Gakkaishi 54 (7), 1123-1129.

Teshima, S., Kanazawa, A., Koshio, S., Horinouchi, K., 1989. Lipid metabolism of the prawn Penaeus japonicus during maturation: variation in lipid profiles of the ovary and hepatopancreas. Comp. Biochem. Physiol. 92B, 45-49.

Verstraete, P., De La Mora, B., Lavens, P., 1995. Maturation of Penaeus vannamei by using dry pellets as a partial substitute of the natural diet. Larvi'95, Gent, European Aquaculture Society, Special Publication, vol. 24 , pp. $76-78$.

Vincent, M., Ramos, L., Oliva, L., 1988. Variations qualitatives et quantitatives des pigments caroténoïdes dans l'ovaire et l' hepatopancréas de Penaeus schmitti au cours de la maturations ovarienne. Arch. Int. Physiol. Biochim. 96, 155-164.

Wouters, R., Gómez, L., Lavens, P., Calderón, J., 1999a. Feeding enriched Artemia biomassa to Penaeus vannamei broodstock: its effect on reproductive performance and larval quality. J. Shellfish Res. 18 (2), 651-656.

Wouters, R., Molina, C., Lavens, P., Calderón, J., 1999b. Contenido de lípidos y vitaminas en reproductores silvestres durante la maduración ovárica y en nauplios de Penaeus vannamei. Proceedings of the Fifth Ecuadorian Aquaculture Conference, Guayaquil, Ecuador, Fundación CENAIM-ESPOL, CDRom.

Wouters, R., Zambrano, B., Mendoza, S., Espín, M., Lavens, P., 2000a. Ensayos con una dieta artificial de maduración basada en harina de Artemia. Mundo Acuicola 6 (1), 17-20. 
Wouters, R., Nieto, J., Sorgeloos, P., 2000b. Artificial diets for Penaeid shrimp. Global Aquacult. Advocate 3 (2), 61-62.

Wyban, J., Martinez, G., Sweeney, J., 1997. Adding paprika to Penaeus vannamei maturation diet improves nauplii quality. World Aquacult. 28, 59-62.

Xu, X.L., Ji, W.L., Castell, J.D., O’Dor, R.K., 1994. Influence of dietary lipid sources on fecundity, egg hatchability and fatty acid composition of Chinese prawn (Penaeus chinensis) broodstock. Aquaculture $119,359-370$. 